\title{
SOVEREIGN WEALTH FUNDS: THE CASE OF NORWAY
}

\author{
Hüseyin Burak ÖZGÜL ${ }^{1}$
}

\begin{abstract}
Sovereign Wealth Funds that emerged in the mid-twentieth century and whose numbers have largely grown since then, have become an important issue at the heart of discussions today. In this context, The Government Pension Fund-Global, established under the name of Government Petroleum Fund in 1990, attracts the attention as the largest sovereign wealth fund in the world today. Particularly good governance, transparency, importance of ethical values in investments, consistently dynamic structure are the main factors that feature in the development of the fund. Hence, in the study, The Government Pension Fund-Global has been examined in terms of guiding to Turkey Wealth Fund, established in 2016 and one of the world's newest fund.
\end{abstract}

Keywords: Sovereign Wealth Funds, The Government Pension Fund of Norway, The Government Pension FundGlobal, The Government Petroleum Fund of Norway

JEL Code: F30, G23, G38.

\section{Introduction}

The term "Sovereign Wealth Fund" was first used in 2005 by Andrew Rozanov, one of the State Street Bank of America. Rozanov indicated that by betterment of macroeconomy, terms of trade and financial stability of a country and implementation of financial spending limitation policy, budget surplus and foreign trade surplus accumulate. He stated that therefore, to manage the surplus at issue, investment institutions were established, and they could be called Sovereign Wealth Funds (Ping \& Chao, 2009: 2).

There are three key features of Wealth Funds. First of these features is that Wealth Funds are stated-controlled. Second, they mainly invest abroad. Third, they are established in accordance with long term objectives, by and large to implement macroeconomic objectives. Thus, assets of the Fund, is different from the Central Bank reserves, the purpose of which is only to equilibrate balance of payments and should not be confused with other institutions, and establishments, and funds (IWG, 2008: 27) .

Sovereign Wealth Funds, though it emerged as a financial issue in $21^{\text {st }}$ century, they date back to a long time. In literature, it is stated that the first modern sovereign wealth fund in line with IMF definition is the one established in Kuwait in 1953 to manage surplus of income from oil (Alheshel, 2015: 2).

The Funds which were few in 1950s, from the end of 90s, increased enormously in number and the Funds at issue spread to the world. Today, there are 78 Sovereign Wealth Funds in 50 countries in total (SWFI Institute, 2019).

\footnotetext{
1 Res. Asst., Istanbul University, burak.ozgul@istanbul.edu.tr

2 For further information on sovereign wealth funds. See: (Özgül, 2018).
} 
Among these funds, Government Pension Fund is the subject of this research, as it has the biggest asset value and it is shown as a model in terms of transparency.

\section{Government Pension Fund Global (GPFG)}

According to Sovereign Wealth Fund Institute data, by 2019, GPFG is the biggest fund in the world with an asset value higher than 1 trillion dollar ${ }^{3}$. Moreover, on LMT index, used by the institute as transparency index, it scored 10 over 10 . The fund at issue is commonly described as a transparent and well-managed and it is praised by the media around the world for leading the responsible investment enterprises on ethical and social grounds (Clark \&Monk, 2010: 14).

\subsection{Historical Development}

The Sovereign Wealth Fund of Norway is directly linked to the drilling of oil resources in the country. In Norway, oil was first discovered in the North Sea in 1969. Two years after its discovery, the oil production began. And in 1990s, a significant revenue from oil production accumulated. Norwegian Government launched Government Petroleum Fund as a means to support longterm management of ever-increasing oil revenue. The Fund at issue was founded by passing of Government Petroleum Fund Law by Norwegian Parliament in 1990 (Backer, 2009: 132) ${ }^{4}$.

One of the most significant reasons to found the fund was to make clearer how the oil revenue was used. In this context, it was aimed to compile the mentioned revenue under a fund and use them to cope with difficulties that might occur in public finance in long term because of the fluctuations in the oil revenue (Norges Bank, 1998:4) By doing so, it is aimed to create a long-term prosperity source to finance the social security spendings that might occur as a result of the population growth in the future and to benefit future generations (Legislative Council Secretariat, 2014: 1).

Fund mechanism was designed in a way that transfer to Fund could be made only when there is budget surplus. For this reason, between 1990-1995, no transfer was done to the fund. Because, due to the recession in the country in the first half of 1990s, budget deficits occurred. After this period, first budget surplus occurred in 1995 and capital transfer to the fund from that year's budget surplus took place in 1996 (Skancke, 2003: 318). The fund which was renamed "Government Pension Fund" in 2006 (Clark \&Monk, 2010: 14), from 1996 when it acquired the first capital transfer to today, it has been ever growing and in 2019, with its asset value of more than 1 trillion dollars, it has become the biggest sovereign wealth fund in the world. (SWFI Institute, 2019).

\footnotetext{
3 The value at issue constitutes \%13 of the total value (as of 2019 8,144 trillion dollars) of all the sovereign wealth funds.

${ }^{4}$ After oil was discovered in 1969, it was realised by the Norwegian Government that the oil revenue would be high. And also, it was weel-understood that the oil revenue is not a renewable income and it would be affected by economical fluctuations. For these reasons, managing the oil revenue and spending of the state became important and the idea to establish a sovereign wealth fund was first suggested by Tempo Commitee in 1983. And in the long term programme released in the spring of 1986, the Norwegian government supported the idea (Norwegian Ministary of Finance, 2013: 7).
} 


\subsection{Governance Structure}

As is today, The Government Pension Fund consists of the Government Pension Fund Global and Government Pension Fund Norway (Government Petroleum Fund Act, 1990). The Government Pension Fund Norway involves (Folketrygdfondet) National Insurance Scheme Fund Norway (Norwegian Ministry of Finance, 2006: 5-6). Along with this, well-known in the world, displaying sovereign wealth fund features i.e. making investments abroad, The Government Pension Fund Global (GPFG) is the main subject of this study. ${ }^{5}$

GPFG has not got executive board or administrative personnel. According to law, GPFG is administrated by the Ministry of Finance. Administration of the fund is divided into three parts. The first part includes formation of general policy. This function belongs to the Ministry of Finance. Ministry of Finance sets out principles of ethical and institutional management principles along with fund's investment strategies (Norwegian Ministry of Finance, 2006: 6). The second part is the administration. The operational administration of the fund is transferred to Norway Central Bank (Norges Bank). Within this scope, a management agreement was made between Ministry of Finance and the Norway Central Bank to regulate the task sharing (Figure 1) (Norges Bank, 2008: 6).

It's not possible that the operational management of GPFG is regulated and administrated in a detailed manner by the Ministry of Finance. The authority of regulation only states the general investment strategy. Norges Bank is responsible with making investment decisions independently of The Ministry. The responsibility to accept investment strategies and other high affairs belongs to Executive Board in Norges Bank. Daily operations are given to the chair of the Norges Bank Investment Management (Norwegian Ministry of Finance, 2018: 58). In this context, the chair of the Norges Bank Investment Administration reports to the Norges Bank manager monthly; however, does not participate in the internal discussions on Central Bank's general monetary policy (Skancke, 2003: 330).

\footnotetext{
5 Norwegian Wealth Fund carried on its activies as State Oil Fund from 1990 to 2006 and in 2006, it was renamed Government Pension Fund, with the merging of Goverment Pension Fund-Norway which involved National Insurance Fund and Government Pension Fund-Global which was continituation of Government Petroleum Fund.
} 
Figure 1. Governance Structure of GPFG

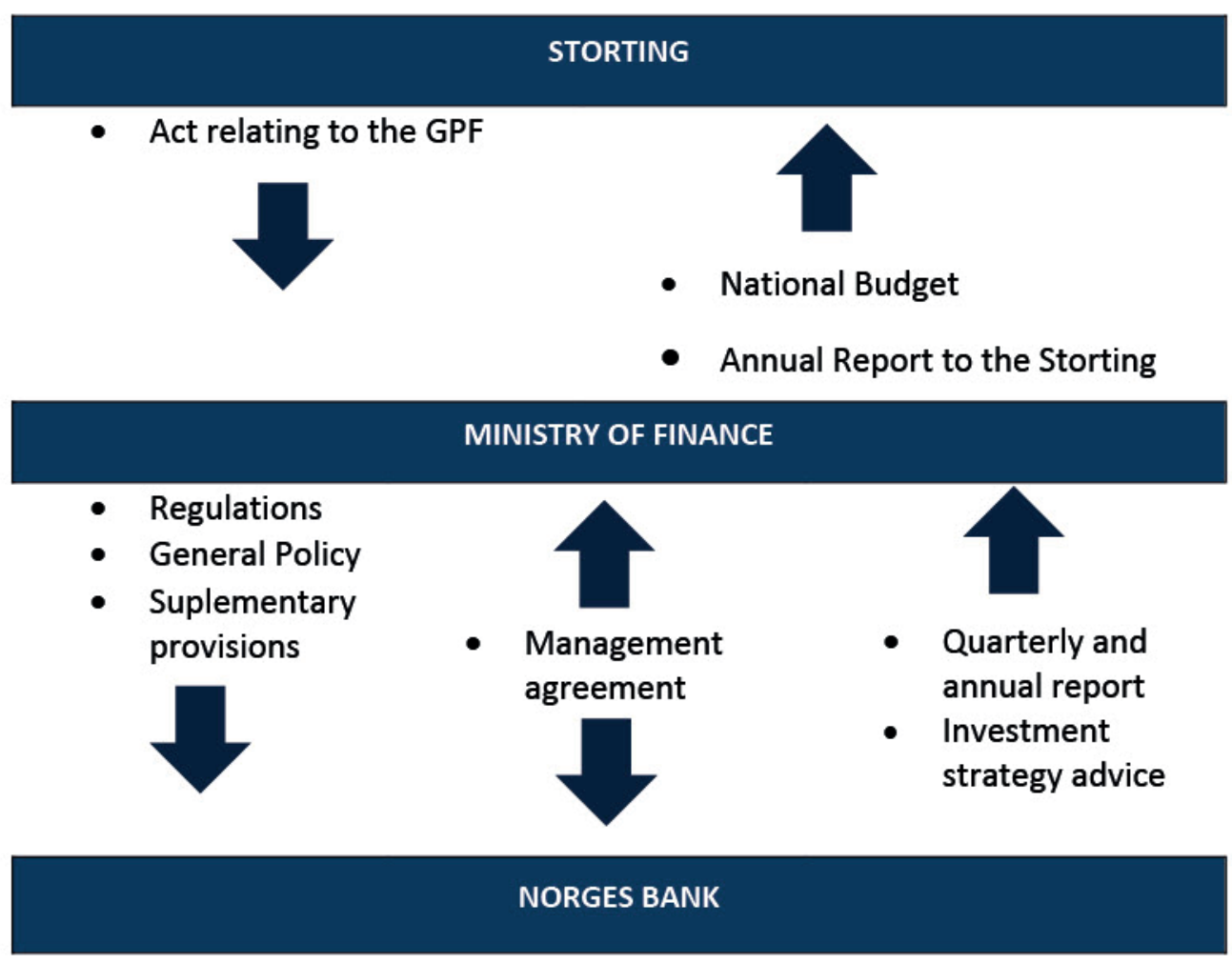

Source: Norges Bank, 2008: 7.

Third part is the supervision (Figure 2). Norges Bank files a detailed annual report about the management of the sovereign wealth fund. These public reports, explains how the fund is managed and includes a list of the companies the fund invests in. These reports also include information such as the investment view and the election process of the exterior managers. In addition, Norges Bank files quarterly reports including main revenue and cost data. Apart from all these, Norges Bank reports to an independent company too. The reports of this company are public and published online as the Norges Bank's reports (Skancke, 2003: 328-329).

The Ministry of Finance, to which the Fund is affiliated, every year at the spring session, presents a report (White paper) about the management of the fund to the parliament. These reports are public. In the attachment of the report, the annual report presented by Norges Bank is also available. In the reports presented by the Ministry of Finance, the general issues about the management of fund capital are presented. More general topics, such as; the management of the oil revenue, the role of the fund in the economy and how much of the oil revenue is to be spent are discussed in the autumn session along with the financial year budget (Norwegian Ministry of Finance, 2006: 7). 
Figure 2. Audit of GPFG

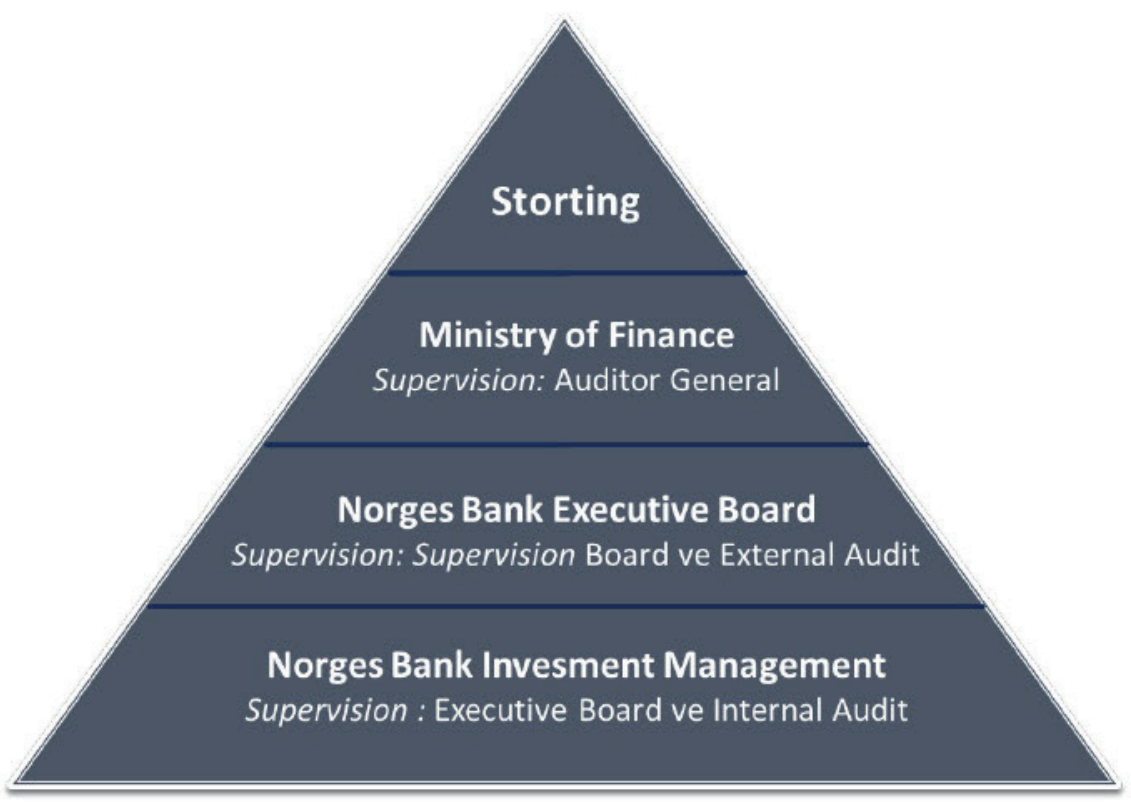

The fund is also audited by the Office of the Auditor General of Norway. The office is responsible with the ultimate audit of the fund and reports directly to the parliament (Backer, 2009: 139).

\subsection{Operational Mechanism}

The revenues of GPFG are provided from the cash flow coming from the oil-related activities which is transferred from the fiscal budget, from the results of financial transactions -related to oil-related activities, and returns of the fund capital. In compliance with the decision made by the Norwegian Parliament, the capital of the GPFG can be only used in the transfers to the fiscal budget (Government Petroleum Fund Act, 1990).

Figure 3. Fund Structure

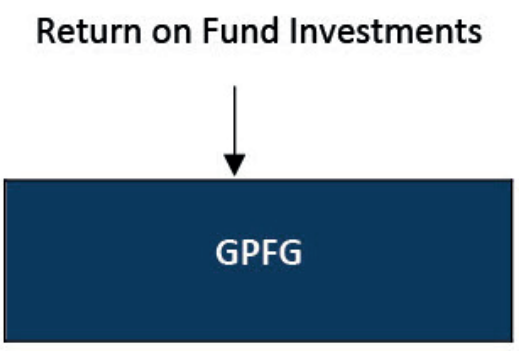

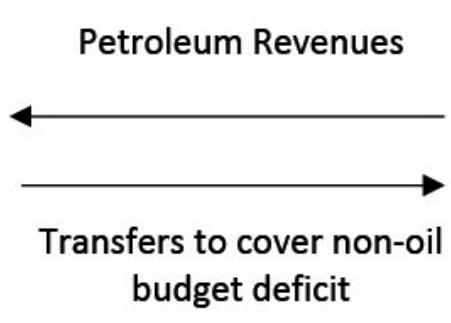

budget deficit
All Revenues

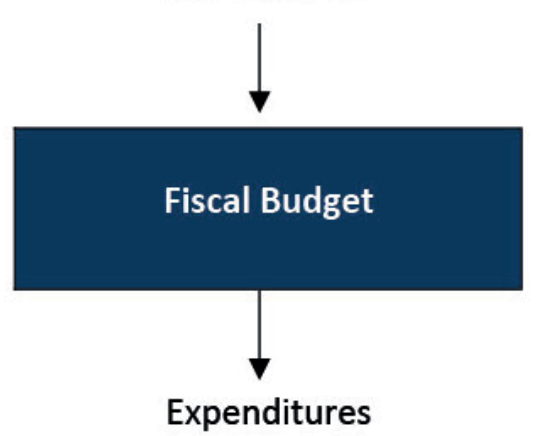

Source: Skancke, 2003: 321. 
As shown in figure 3 , in this context, the spending of the fund consists of the annual transfers to the Treasury to close the budget deficit which occurs apart from the oil revenue in the fiscal budget (Skancke, 2003: 322).

However, the transfer is limited. Authorities made a regulation in 2001 to allow only \%4 of the fund-asset of that year to be transferred to close this deficit. In determining $\% 4$ ratio which is also called the fiscal rule, fund's expected rate of return from its investments was considered (Wirth, 2018: 184) and this ratio was reorganized as \%3 in 2017. It is expressed that, by this means, the transfers which are to be made to the fiscal budget from the fund would be levelled in time to the fund's expected actual rate of return (Norwegian Ministry of Finance, 2019).

While on one hand, the Norwegian Ministry of Finance asserted that the oil income was not permanent and could be affected by the financial fluctuations easily, on the other hand it emphasized that fund's expected net return could finance the budget deficits in time as a permanent income. It is assumed that thereby the effect of the financial fluctuations on the budget could be prevented (Norwegian Ministry of Finance, 2006: 8).

\subsection{Investment Strategy}

As mentioned earlier, Norway Wealth Fund got the first capital in 1996, after its formation in 1990. Until 1998, the fund capital was managed in the same manner as Norway Central Bank foreign exchange reserve. In the beginning, GPFG only made investments in fixed-income security including government bonds and government-guaranteed investment grade securities in only 8 countries (Norwegian Ministry of Finance, 2014: 15).

The Fund started preparations to invest in equities in 1997 and established a new department called Norges Bank Investment Management in the first quarter of 1998 to manage these investments and transferred the assets which was 14 billion euro at that time to this department (Skancke, 2003: 330). The fund started to invest equity investments with \%40 initial share after this. The idea behind this spurt was that equities would bring more profit than government bonds in the long term. By this means, it was predicted that investing in multiple asset classes would help spreading the risk (Norwegian Ministry of Finance, 2014: 15).

In 2000, some developing markets were included in the equities and fund investments was expanded to include 21 countries. In 2002, non-government guaranteed bonds were included in the fixed-income benchmark. In 2007, the share of equity investments was raised from $\% 40$ to $\% 60$ (\%70 today). In 2008, the scope of equity investments was expanded even further including all the developing markets ${ }^{6}$ (Norwegian Ministry of Finance, 2014: 17).

Again, the fund was allowed to make real estate investment up to $\% 5$ (\%7 today) in 2008 . First real estate investments were made in big European cities. After 2013, investment strategy of GPFG was changed so that real estate investments could be done in global scale (Norwegian Ministry of Finance, 2014: 18).

\footnotetext{
6 These markets are all markets defined by FTSE Group as Advanced Emerging and Secondary Emerging. For more information see https://www.ftse.com/products/indices/country-classification (26.02.2019).
} 
Chart 1. Investment Distribution of GPFG (Third Quarter of 2018) (\%)

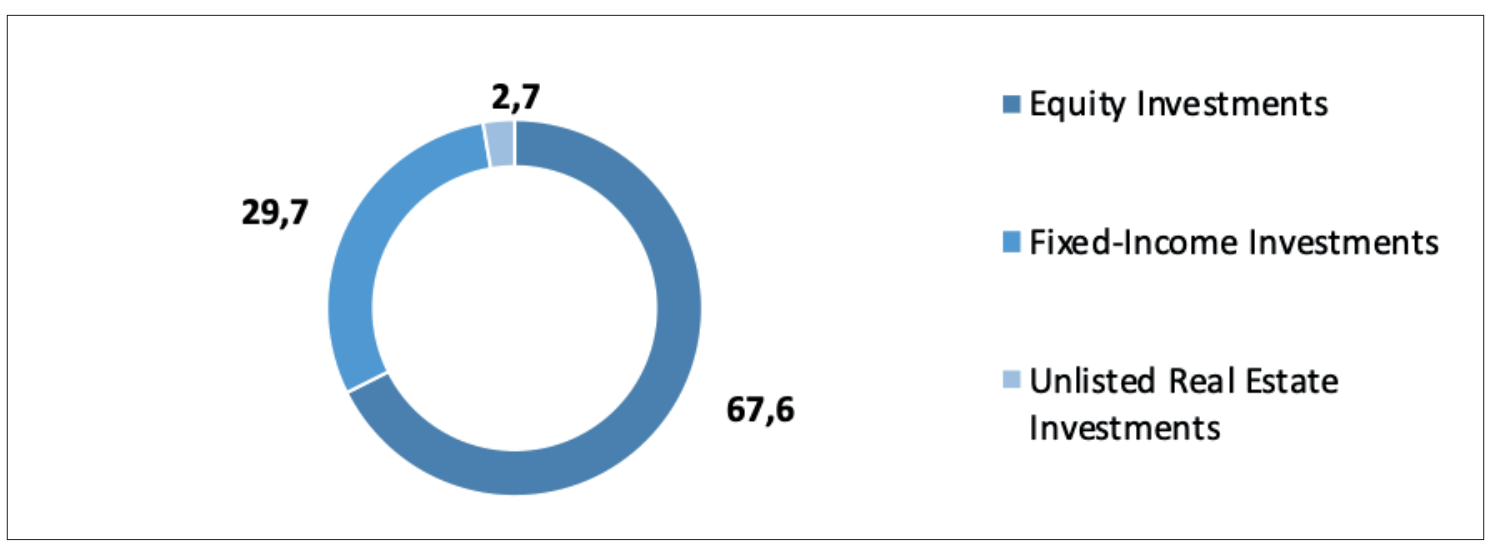

Source: Norges Bank, 2018: 4.

Today, the funds make investments in more than 9000 companies in 72 countries (Norges Bank, 2017: 26). As shown in Chart 1, the biggest percentage of GPFG's investments is consists of equity investments with $\% 67,6$. It is seen that most investments are made in finance, industry, and technology sectors (Chart 2).

Chart 2. Sectoral Distribution of Equity Investments (Third Quarter of 2018) (\%)

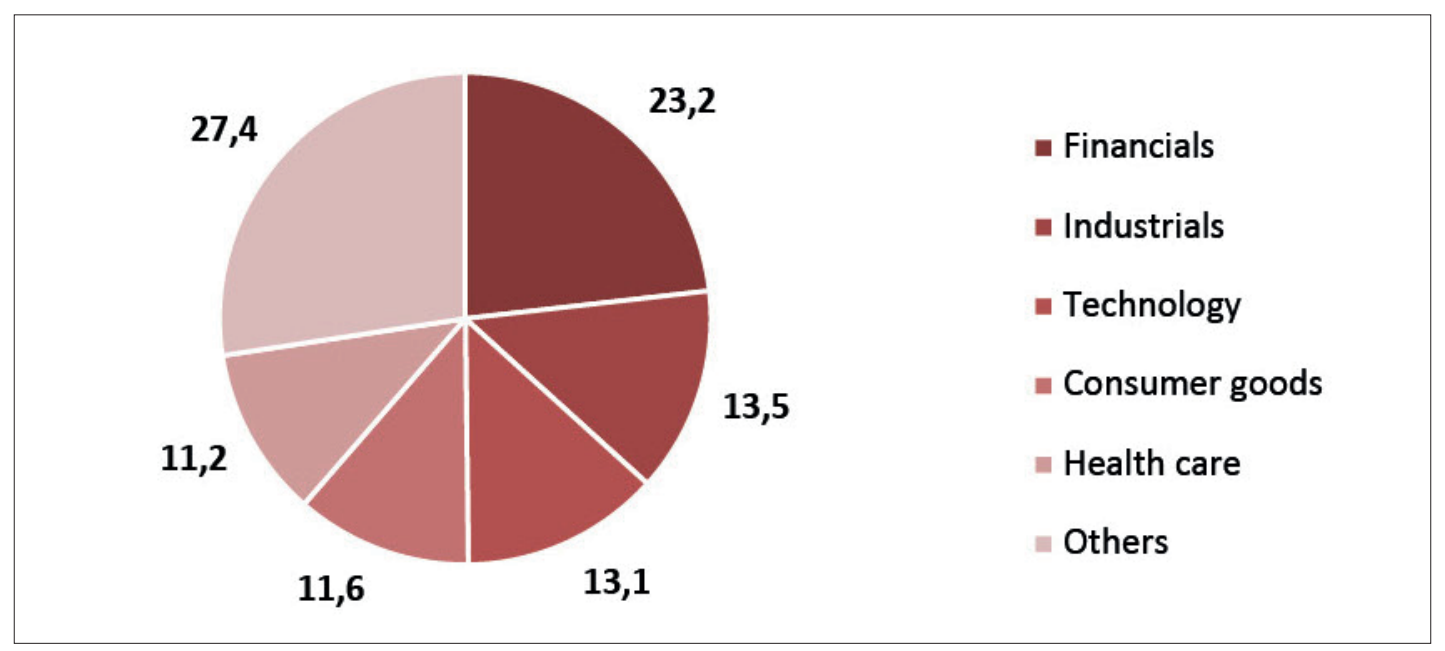

Source: Norges Bank, 2018: 7.

As shown in chart 3, the biggest percentage in regional distribution of GPFG's investments is in North America region. That is followed by Europe with \%36. Country based, $\% 36$ of the distribution is in the U.S., \%8,8 in the U.K, and \%8,7 is in Japan (Norges Bank, 2017: 27). 
Chart 3. The Regional Distribution of The Fund's Investments (End of 2017) (\%)

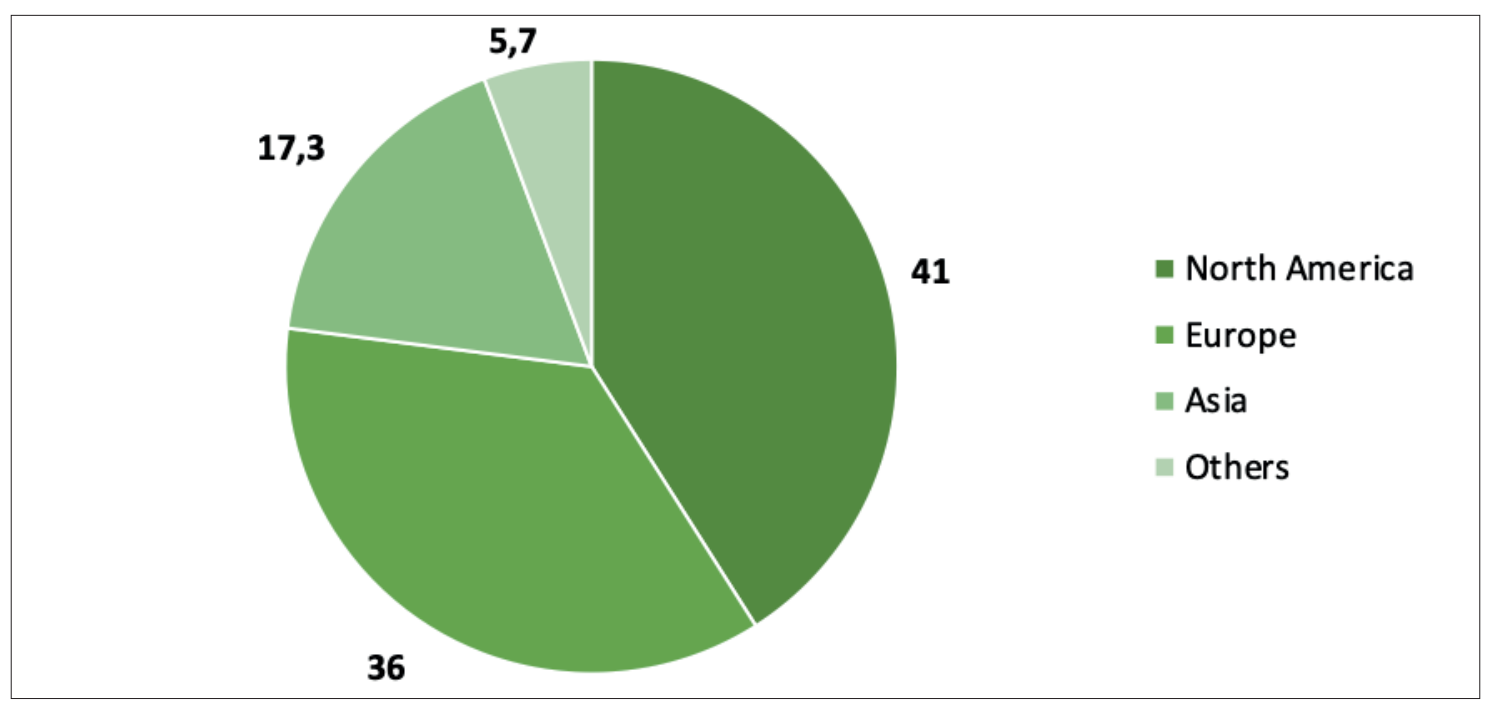

Source: Norges Bank, 2017: 27.

The biggest reasons why GPFG became the biggest wealth fund and the investments developed this much are good management and transparency. In many reports reviewed and articles written, it is seen that attention is drawn to the understanding of transparent management since its formation. The important part of this is The Council on Ethics.

\subsubsection{The Council on Ethics}

Besides being officially affiliated to the Ministry of Finance, at the same time, GPFG is the property of Norwegian citizens. Thus, it can be affected by the public. In 1998 when the fund started making equity investments, it was opined by the citizens that the fund should not only be used for intergenerational justice, but also it should contribute to the universally accepted values and norms. Because, in those years, it was revealed in report that the fund was investing in many companies which took part in unethical activities (Wirth, 2018: 186).

Upon this, in 2002 The Ministry of Finance formed a commission. In the report released by the commission in 2003; internationally accepted ethical values regarding human rights, governance, and protection of environment depending on UN and OECD principals were defined. In the report, in particular the necessity of two main values was underlined. The first of the mentioned values was the compulsion to intergenerational distribution of the oil revenue even if petroleum revenue was low. The second was company that are to be invested in have to be respectful to the basic rights and liberties. At the end of 2004, the parliament passed the Ethical Guidelines for the GPFG (Wirth, 2018: 186-187).

Also, in this session The Council on Ethics was established. The council is an independent one responsible for counselling the Ministry of Finance and Norges Bank ${ }^{7}$. The council's responsibility is to check whether the companies that are to be invested in comply with accepted ethical criteria. Until today, the council has given advice to Norges Bank on many companies that

\footnotetext{
7 The investment advice was passed to the Ministry of Finance until 2015, then directly to Norges Bank.
} 
violate the ethical rules. And most of the time, Norges Bank followed their advice, though it is not compulsory for the bank to follow the given advice (Council on Ethics Government Pension Fund-Global, 2005: 5, 2017: 7) ${ }^{8}$.

\section{General Evaluation}

For the financial authorities in a country, the priority should be the development of cautios and long term strategy for finance policy. However, if this strategy requires the state to accumulate its resources and form a sovereign wealth fund, then there is the necessity to make the detailed regulations for the mentioned fund. The success of the fund requires high consensus, transparency, and accountability. As in the example of Norway, it was possible that an institutional frame could be formed in 1990 when the fund was established. Because, at that time, the Central Bank had vast experience on how to manage the foreign exchange reserves and a well-functioning reporting and control systems. Additionally, for financial policy strategy and the operations of the central bank, there is the long tradition of transparency in the country. Moreover, the contract between the Ministry of Finance to which the fund is affiliated and the Central Bank that runs the operational management of the fund helped the good management of the fund by stating the duties and responsibilities of the parties clearly. Correspondingly, it is required for the countries that take GPFG as an example, they should develop the institutions to regulate transparency, accountability and budget operations, and establish a tradition of transparency (Scancke, 2003: 333).

\section{Conclusion}

The total value of sovereign wealth funds whose numbers are 78 today, has risen to 8.144 trillion dollars today. \%13 of the total value belongs to the GPFG alone. The fund having got the allocation of capital for the first time in 1996, firstly made investments in fixed income securities and then started making equity investments. Today, it is the biggest wealth fund in the world investing in more than 2000 companies in 72 countries.

It is the subject of another research whether the wealth in the countries of the sovereign wealth funds establish before and after the fund at issue is more than Norway. However, as from 1990 when Norway Wealth Fund was established, it is a significant fact that it was realized that the oil source of the fund would not be a permanent income and to finance the ever since growing elderly population's expenses in the future, by managing the mentioned oil resources well it reached it's success today. The most important reasons behind this success are that the first day the fund was established on, transparency and accountability were prioritized and wellplanned management of the oil revenue.

\footnotetext{
8 Council in the companies to be invested; It pays attention to the existence of many situations such as human rights violations such as murder, torture, child labor and all forms of child exploitation, severe environmental damages, arms production, greenhouse emissions, corruption and serious violations of basic ethical norms (Council on Ethics Government Pension Fund-Global, 2005: 6).
} 


\section{References}

Alheshel, B. (2015). "Sovereign Wealth Funds: A Literature Review", Journal of Economics and Business, Vol: 78, pp. 1-13.

Backer, L. C. (2009). "Sovereign Wealth Funds as Regulatory Chameleons: The Norwegian Sovereign Wealth Funds and Public Global Governance Through Private Global Investment", Georgetown Journal of International Law, Vol: 41 (2), pp. 101-192.

Clark, G. L. \& Monk, A. (2010). "The Norwegian Government Pension Fund: Ethics Over Efficiency", Rotman International Journal of Pension Management, Vol: 3 (1), pp. 14-19.

Council on Ethics Government Pension Fund-Global. (2005). Annual Report 2005, https:// etikkradet.no/annual-reports/\%22https://nettsteder.regjeringen.no/etikkradet3/files /2017/02/rsmelding-2005-eng-1.pdf, (25.02.2019).

Council on Ethics Government Pension Fund-Global. (2017). Annual Report 2017, https:// nettsteder.regjeringen.no/etikkradet3/files/2018/03/Etikkradet_arsmelding_2017_eng_ UU.pdf, (25.02.2019).

Government Petroleum Fund Act. (1990). https://www.ilo.org/dyn/natlex/docs/ELECTRONIC/ 73096/101041/F1862112044/NOR73096\%20ENG.pdf, (25.02.2019).

IWG. (2008). Sovereign Wealth Funds: Generally Accepted Principles and Practices "Santiago Principles", https://www.ifswf.org/sites/default/files/santiagoprinciples_0_0.pdf, (25.02.2019).

Legislative Council Secretariat. (2014). Fact Sheet- Government Pension Fund of Norway, https:// www.legco.gov.hk/research-publications/english/1314fsc50-government-pension-fundof-norway-20140902-e.pdf, (25.02.2019).

Norges Bank. (2008). Government Pension Fund-Global Annual Report, https://www.nbim.no/ globalassets/reports/2008/2008-annual-report.pdf, (25.02.2019)

Norges Bank. (2017). Government Pension Fund-Global Annual Report, https://www.nbim.no/ contentassets/49715a01ed684b1686ff3c017f1efa12/annual-report-2017---governmentpension-fund-global.pdf, (25.02.2019).

Norges Bank. (2018). Government Pension Fund-Global Quarterly Report-3Q, https://www. nbim.no/contentassets/6ca8926d402d484b85569addb7697992/gpfg-3q-2018-quarterlyreport.pdf, (25.02.2019).

Norwegian Ministry of Finance. (2006). On the Management of the Government Pension Fund in 2006, https://www.regjeringen.no/contentassets/eeb49ccf49b94cfe881fdaa678efa537/en-gb /pdfs/stm200620070024000en_pdfs.pdf, (25.02.2019).

Norwegian Ministry of Finance. (2014). The Management of the Government Pension Fund in 2014, https://www.regjeringen.no/contentassets/48bb4314d6f14d23aff45960dc3eaace /en-gb/pdfs/stm201420150021000engpdfs.pdf, (25.02.2019).

Norwegian Ministry of Finance. (2018). The Government Pension Fund 2018, https://www. regjeringen.no/contentassets/569f03a08ee74350b3778fdbb24dd406/en-gb/pdfs/ stm201720180013000engpdfs.pdf, (25.05.2019). 
Norwegian Ministry of Finance. (2019). The Norwegian Fiscal Policy Framework, https://www. regjeringen.no/en/topics/the-economy/economic-policy/economic-policy/id418083/, (25.02.2019).

Özgül, H. B. (2018). "Sovereign Wealth Funds and Turkey Wealth Fund", (Master's Thesis), Marmara University Institute of Social Sciences, Istanbul.

Ping, X. \& Chao, C. (2009). "The Theoretical Logic of Sovereign Wealth Funds", https://papers. ssrn.com/sol3/papers.cfm?abstract_id=1420618, (25.02.2019).

Skancke, M. (2003). "Fiscal Policy and Petroleum Fund Management in Norway", Fiscal Policy Formulation and Implementation in Oil-Producing Countries, (Ed.) Davis, J. M., Ossowski, R. \& Fedilino, A., Washington D. C., International Monetary Fund, pp. 316-338.

SWFI Institue. (2019). https://www.swfinstitute.org/sovereign-wealth-fund-rankings/, (25.02.2019).

Wirth, E. (2018). "The Norwegian Government Pension Fund Global, Corporate Social Responsibility And Climate Change", Revista De Economía Mundial, No: 48, pp. 179-189. 